\title{
AnNual Grasses Control with TOpRamezone in MiXture with ALS-INHIBITING HERBICIDES ${ }^{1}$
}

\author{
Controle de Gramíneas Anuais com Topramezone em Misturas com Herbicidas Inibidores da
} ALS

\author{
DAMALAS, C.A. ${ }^{2}$, GITSOPOULOS, T.K. ${ }^{3}$, KOUTROUBAS, S.D. ${ }^{2}$, and GEORGOULAS, I. $^{3}$
}

\begin{abstract}
Panicoid grasses are major weeds of maize and sugarcane as well as of several other important grains, including sorghum, pearl millet, and foxtail millet. Pot trials were conducted to study the activity and potential interactions of topramezone in mixture with recommended rates of rimsulfuron or nicosulfuron on three annual panicoid grasses (i.e. Echinochloa oryzoides, E. phyllopogon, and Panicum miliaceum). Target weeds were treated at the four- to five-leaf growth stage. On the basis of fresh weight reduction, topramezone alone provided $78 \%$ control of E. oryzoides, $68 \%$ control of E. phyllopogon, and $99 \%$ control of $P$. miliaceum. Topramezone plus rimsulfuron or nicosulfuron provided decreased control of both Echinochloa spp. compared with topramezone alone. The decreased control of E. oryzoides and E. phyllopogon was more pronounced with rimsulfuron as a companion herbicide in the mixtures. Slightly decreased control of $P$. milaceum was observed with topramezone plus rimsulfuron compared with topramezone alone, but this was not the case for topramezone plus nicosulfuron. Increased topramezone rates mixed with rimsulfuron or nicosulfuron did not improve control of $E$. oryzoides and E. phyllopogon compared with the lowest topramezone rate. Also, increased topramezone rates mixed with rimsulfuron or nicosulfuron showed decreased control of both Echinochloa spp. when compared with either rimsulfuron or nicosulfuron alone, suggesting a two-way interaction between topramezone and the ALS-inhibiting herbicides. The above-mentioned interaction was not observed in P. miliaceum, probably related with species sensitivity to the herbicides tested. Newly introduced or naturalized panicoid grasses in maize fields may complicate selection of companion herbicides and rates for effective weed control.
\end{abstract}

Keywords: efficacy, nicosulfuron, mixtures, rimsulfuron.

\begin{abstract}
RESUMO - As gramíneas da subfamília Panicoideae são as principais plantas daninhas de milho e cana-de-açúcar, bem como de vários outros grãos importantes, incluindo sorgo, milheto e painço. Ensaios em vasos foram conduzidos para estudar a atividade e interações possiveis de topramezone em misturas com doses recomendadas de rimsulfuron ou nicosulfuron, sobre três gramineas anuais da subfamília Panicoideae (Echinochloa oryzoides, E. phyllopogon e Panicum miliaceum). As gramineas foram tratadas no periodo de crescimento de quatro a cinco folhas. Com base na redução de peso fresco, o topramezone isoladamente apresentou 78\% de controle de $\boldsymbol{E}$. oryzoides, $68 \%$ de $\boldsymbol{E}$. phyllopogon e 99\% de $\boldsymbol{P}$. miliaceum. Topramezone mais rimsulfuron ou nicosulfuron mostrou controle reduzido de ambas as Echinochloa spp., em comparação com topramezone isolado. $O$ controle reduzido de $\boldsymbol{E}$. oryzoides e $\boldsymbol{E}$. phyllopogon foi mais pronunciado com rimsulfuron como herbicida acompanhante nas misturas. Controle ligeiramente reduzido de $\boldsymbol{P}$. milaceum foi observado com topramezone mais rimsulfuron, comparado ao topramezone sozinho, o que não ocorreu com topramezone mais nicosulfuron. Doses aumentadas de topramezone em mistura com rimsulfuron ou nicosulfuron não melhoraram o controle de $\boldsymbol{E}$. oryzoides e $\boldsymbol{E}$. phyllopogon em comparação com a dose mais baixa de topramezone. Além disso, doses aumentadas de topramezone em mistura com
\end{abstract}

Recebido para publicação em 2.1.2015 e aprovado em 15.4.2015.

2 Democritus University of Thrace, GR-68200 Orestiada, Greece, <damalas@mail.gr, cdamalas@agro.duth.gr>; ${ }^{3}$ Research Scientist and Technical Laboratory Staff, Institute of Plant Breeding and Phytogenetic Resources, Hellenic Agricultural Organization-Demeter, GR-57001 Thermi, Thessaloniki, Greece. 
rimsulfuron ou nicosulfuron mostraram controle reduzido de ambas as Echinochloa spp. em comparação com rimsulfuron ou nicosulfuron sozinho, sugerindo uma interação bidirecional entre o topramezone e os herbicidas inibidores da ALS. A interação mencionada não foi observada em P. miliaceum, estando provavelmente relacionada com a sensibilidade das espécies aos herbicidas testados. As gramineas da subfamilia Panicoideae recentemente introduzidas ou naturalizadas nos campos de milho podem complicar a seleção de herbicidas de companhia e doses para o controle eficaz de plantas daninhas.

Palavras-chave: eficácia, nicosulfuron, misturas, rimsulfuron.

\section{INTRODUCTION}

Topramezone is a selective herbicide in the phenyl pyrazolyl ketone chemical family used for postemergence control mainly of broadleaf weeds as well as some grasses in field maize, sweet maize, and popcorn (IMPACT $^{\circledR}$ herbicide, 2007). It has a low use rate with a wide postemergence application window in field maize. Topramezone can be safely applied to maize at the 2- to 8-leaf growth stage, indicating no difference in selectivity, thus providing flexibility in application window (Gitsopoulos et al., 2010). This herbicide inhibits the activity of 4-hydroxyphenylpyruvate dioxygenase (4-HPPD, EC 1.13.11.27), an enzyme catalyzing the catabolism of the common to essentially all aerobic forms of life amino acid tyrosine (Moran, 2005). Inhibition of the activity of 4-HPPD disrupts the biosynthesis of carotenoid pigments in susceptible plants, thus resulting in bleaching (chlorophyll loss) of the foliage, cessation of growth, and ultimately death of the treated plants (Dayan et al., 2007). Maize tolerance to topramezone is due to rapid metabolism of the herbicide to non-active substances and also due to a lower sensitivity of the target site enzyme (Grossmann \& Ehrhardt, 2007).

Although topramezone shows some activity on several annual grasses common to maize production, it may not provide commercially acceptable control of those grasses (Goršić et al., 2008; Soltani et al., 2012). Therefore, tank mixtures of topramezone with other herbicides used in maize are required to provide effective weed control, particularly of the monocotyledonous species. Previous research on compatibility of topramezone with other herbicides used in maize showed that nicosulfuron in mixture with topramezone antagonized topramezone activity for the control of Digitaria sanguinalis and Echinochloa crus-galli under controlled conditions, but did not affect the control of Setaria glauca or S. viridis (Kaastra et al., 2008). Additionally, antagonistic interactions were observed in the field when topramezone was mixed with nicosulfuron or nicosulfuron plus rimsulfuron for the control of E. crus-galli and, to a lesser extent, S. viridis var. major (Kaastra et al., 2008). Yet similar mixtures did not reduce control of S. viridis or Panicum capillare (Kaastra et al., 2008). In another study, the activity of topramezone on volunteer potato plants was not improved when applied in combination with herbicides interfering with the photosystem II (PS-II inhibitors), and in some instances appeared to antagonize control (Koepke-Hill et al., 2010).

Farmers' toolbox for weed control in maize contains a wide variety of herbicides with different modes of action. However, newly introduced or naturalized panicoid grasses may complicate herbicide selection and rates due to differential sensitivity (Damalas et al., 2012; De Cauwer et al., 2012). Although E. oryzoides and E. phyllopogon (Stapf.) Koss $[=E$. oryzicola Vasinger (Vasinger)] are weeds of rice fields, they can also occur in maize fields (Damalas et al., 2012). Maize is a common crop after rice in Greece (Damalas et al., 2012) as well as in California (Williams, 2010).

Combinations of two or more herbicides either in pre-packaged mixtures or by mixing products before application are of great benefit to producers because it can broaden weed control spectrum and thus can allow control of a great variety of weed species with one application (Damalas, 2004). Besides, herbicide 
mixtures can enhance efficacy on certain weed species than herbicides applied alone (Damalas, 2004). In addition, herbicide mixtures can be more efficient than sequential applications by allowing better use of time, labor, and machinery, thus reducing production costs. Yet potential interactions between companion herbicides may antagonize the biological activity of each single herbicide in mixture resulting in undesirable reduced weed control (Damalas et al., 2006).

An understanding of how herbicides perform in mixtures is critical to the positioning of new herbicide products in the marketplace (Kaastra et al., 2008). In addition, to the best of our knowledge, postemergence activity of topramezone either alone or in mixture with ALS-inhibiting herbicides has not been studied on naturalized Echinochloa spp., such as E. oryzoides and E. phyllopogon. Therefore, the objective of this research was to study the activity and potential interactions of topramezone in mixture with recommended rates of rimsulfuron or nicosulfuron on three annual grasses (i.e. E. oryzoides, E. phyllopogon, and Panicum miliaceum).

\section{MATERIALS AND METHODS}

\section{Plant material}

Seeds of E. oryzoides and E. phyllopogon were hand-collected from mature plants grown in rice fields of Thessaloniki in northern Greece. Seeds were collected at seed shedding from mature panicles. Distinction of the two Echinochloa spp. was based on inflorescence morphological traits as described by Carretero (1981) and flowering time in rice fields (Damalas et al., 2008). In general, the classification of Echinochloa spp. is rather difficult because of the existence of numerous intergrading polymorphic complexes with many subspecies and varieties which often lack conspicuous identification characters. Nomenclature for the Echinochloa spp. used in this study was based on the classification proposed by Carretero (1981). After collection, seeds were air-dried in the greenhouse, aircleaned to remove non-viable seeds and waste materials, and then stored in plastic bags at $5-6{ }^{\circ} \mathrm{C}$ (in a refrigerator), as a usual practice of long-term seed storage, until experiment initiation. Seeds of Panicum miliaceum were purchased from the local market (product in bulk with no brand name) and stored in a similar way.

\section{Pot trials and herbicide treatments}

The trials of this study were conducted at the Department of Agricultural Development (Democritus University of Thrace) in Orestiada, Greece in the spring of 2011 and at the Plant Protection Institute of Thessaloniki (Hellenic Agricultural Organization-Demeter) in Thermi, Greece in the spring of 2013. Preliminary experiments (not reported in this study) were conducted both in Orestiada and Thermi to see a first response of the mixtures and determine a rate structure. After release of seed dormancy through soaking seeds in concentrated sulfuric acid (95-97\%) for 3 min, rinsing with tap water afterwards, and then air-drying, seeds of E. oryzoides, E. phyllopogon, and P. miliaceum were planted in mid spring of 2011 at Orestiada in 0.65-L cylindrical plastic pots filled with a commercial bedding substrate (fertilized substrate based on white sphagnum peat moss) with $\mathrm{pH}$ 6.0. The experiments were repeated in 2013 in Thermi in similar plastic pots filled with sieved soil following the same procedure. The soil used at Thermi (2013) was a sandy loam (6.8\% clay, $32.0 \%$ silt, and $61.2 \%$ sand) with $\mathrm{pH} 7.7$, organic matter $1.85 \%, \mathrm{CaCO}_{3} 3.5 \%$,

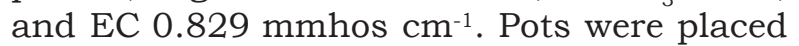
outdoors and watered once daily to soil saturation throughout the experiments. Irrigation patterns were absolutely identical for all pots. One week after seedling emergence, plants were thinned to ten per pot for the two Echinochloa spp. and to five per pot for $P$. miliaceum to obtain a uniform population of each species in all pots. Plants grew normally throughout the experiments without experiencing any particular stress. The main weather parameters in the period of the experiments for 2011 (Orestiada) were: mean air temperature $20.6{ }^{\circ} \mathrm{C}$ and total precipitation $25 \mathrm{~mm}$, whereas the respective values for 2013 (Thermi) were $22.1^{\circ} \mathrm{C}$ and $5.6 \mathrm{~mm}$. 
Topramezone (CLIO 33.6 SC, BASF Hellas, Athens, Greece) was applied alone at 40.3, 50.4 and $60.5 \mathrm{~g}$ a.i. ha ${ }^{-1}$ with methylated seed oil adjuvant (a mixture of fatty acid esters and alkoxylated alcohols-phosphate esters) (DASH HC, BASF Hellas, Athens, Greece) at 0.33\% $\mathrm{v} / \mathrm{v}$, according to the product label, when the three species were at the four- to five-leaf growth stage. The weed growth stage was selected based on the recommendation of topramezone label for grasses (e.g. before tillering stage) and following the usual practice of many farmers for late postemergence applications. The application rates were based on the recommended rates of the product label for maize in Greece (40.3 and $50.4 \mathrm{~g}$ a.i. ha ${ }^{-1}$ ), plus a non-registered rate $(60.5 \mathrm{~g}$ a.i. ha-1) to study the level of tolerance of the three species to the herbicide. Additionally, each topramezone rate mentioned above was mixed with label rates of rimsulfuron (RUSH 25 WG, DuPont Hellas, Athens Greece) (10 g a.i. ha-1) or nicosulfuron (BELIUR 4 SC, Elton International Trading, Avlonas, Attiki, Greece) (40 g a.i. ha $\mathrm{h}^{-1}$ ) and applied at the same growth stage of grasses. Rimsulfuron and nicosulfuron were also applied alone at the same rates to those used in the mixtures. Application rates were based on the recommended rates of the label of each product for weed control in maize in Greece. In all experiments, the mixture treatments of topramezone were applied with the addition of methylated seed oil adjuvant at $0.33 \% \mathrm{v} / \mathrm{v}$, similarly to that of topramezone single treatments (mentioned above), according to topramezone label. A non-treated control was included for comparisons. The experiments were arranged in a completely randomized design with four replications (pots) for each treatment. Herbicide treatments were applied with a propane-pressurized hand-held field plot sprayer at $250 \mathrm{kPa}$ pressure using $300 \mathrm{~L} \mathrm{ha}^{-1}$ of water. Environmental conditions at application time were similar in both study periods (i.e. sunny and mild conditions, with air temperature $22-24{ }^{\circ} \mathrm{C}$ and relative humidity $62-68 \%)$.

\section{Efficacy assessments and statistical analysis}

To capture the early symptoms of herbicide activity, grass species control was evaluated visually 10 days after treatment (DAT), taking into account the overall growth status of the treated plants in each pot (i.e. level of stunting, chlorosis, and injury) compared with the non-treated control. The assessments were performed by at least two experienced individuals on a scale from 0 to $100 \% \quad(0 \%=$ no visual symptoms and $100 \%=$ dead plants) with $5 \%$ increments (the non-treated control corresponded to $0 \%=$ no visual symptoms). Further, grass species control was evaluated by determining fresh weight of surviving plants at 21 DAT. Two days before determining fresh weight, plants were left without irrigation. Fresh weight, one of the simplest measures of plant vigor, is typically used in assessments of herbicide efficacy among other continuous variables, according to common international standards (EPPO, 2007, 2012). Fresh weight data were expressed as a percent reduction from the non-treated control (fresh weight suppression over the nontreated control). Visual ratings and fresh weight data (percent reduction from the nontreated control) were subjected to analysis of variance (ANOVA) with eleven herbicide treatments by four replications, separately for each species. Differences between means were compared at 5\% level of significance using Fisher's protected LSD test (least significance difference). There was no significant time by treatment interaction; thus treatment means were pooled over experiments.

To classify the interaction between herbicides, the results were analyzed based on Colby's model of 'expected response' (Colby, 1967). Thus, the expected percentage of fresh weight reduction of each species was calculated for the combined application of both herbicides based on eq. 1 .

$$
E=(A \times B) / 100
$$

In eq. $1, E$ is the percentage of expected response with respect to the non-treated control, $A$ is the observed response of topramezone at the rates tested, and $B$ is the observed response of either rimsulfuron or nicosulfuron at the rates tested. A Student's paired t-test was used to identify herbicide interactions by comparing the calculated expected value of a rating parameter to the 
observed value at $P<0.05$. Thus, if the observed rating value was significantly lower than the calculated expected value, based on Student's paired t-test, the herbicide interaction was defined as antagonistic. On the other hand, if the observed rating value was significantly greater than the calculated expected value, based on Student's paired t-test, the herbicide interaction was defined as synergistic. When the observed values were not significantly different from the expected values, based on Student's paired t-test, the responses were defined as additive.

\section{RESULTS AND DISCUSSION}

At 10 DAT, visual control of E. oryzoides with topramezone alone at $40.3 \mathrm{~g}$ a.i. ha- ${ }^{-1}$ was on average $71 \%$ (Table 1 ). Visual symptoms of herbicide efficacy included extensive bleaching (whitening of the leaves), a typical symptom of the HPPD-inhibiting herbicides on susceptible plants that was evident within a week after spraying. Increased rates of topramezone did not improve the visual control of E. oryzoides (72-74\%). An average fresh weight reduction of $78 \%$ was observed for $E$. oryzoides at 21 DAT with topramezone alone at $40.3 \mathrm{~g}$ a.i. ha ${ }^{-1}$. When topramezone rate was increased to $60.5 \mathrm{~g}$ a.i. ha-1 $\mathrm{a}^{-1}$ efficacy on E. oryzoides at 21 DAT was improved $(85 \%)$
(Table 1). Topramezone at any rate applied plus rimsulfuron or nicosulfuron showed decreased efficacy on E. oryzoides at either 10 or 21 DAT compared with topramezone alone (Table 1). Rimsulfuron alone was moderately effective on E. oryzoides $(71 \%)$ at 21 DAT; however, rimsulfuron plus topramezone showed decreased control of E. oryzoides (55-61\%) compared with rimsulfuron alone. Nicosulfuron alone was more effective on E. oryzoides $(83 \%)$ than rimsulfuron alone $(71 \%)$ at 21 DAT; however, nicosulfuron plus topramezone showed decreased control of E. oryzoides (61-74\%) compared with nicosulfuron alone (Table 1). The observed reduction in efficacy was more pronounced in the mixtures with rimsulfuron than with nicosulfuron. According to Colby's model, the observed percentages of fresh weight reduction in E. oryzoides occurred by the combined application of topramezone plus rimsulfuron or topramezone plus nicosulfuron were significantly lower than the expected ones, corroborating antagonistic interaction of topramezone with rimsulfuron or with nicosulfuron in mixture (Table 1). It should be noted that plants of $E$. oryzoides treated with the herbicide mixtures did not express the typical visible symptoms of injury of either group of herbicides used (i.e. bleaching of the leaves for topramezone and interveinal

Table 1 - Control of E. oryzoides with topramezone alone and in mixtures applied at the 4- to 5-leaf growth stage (means are pooled over two locations)

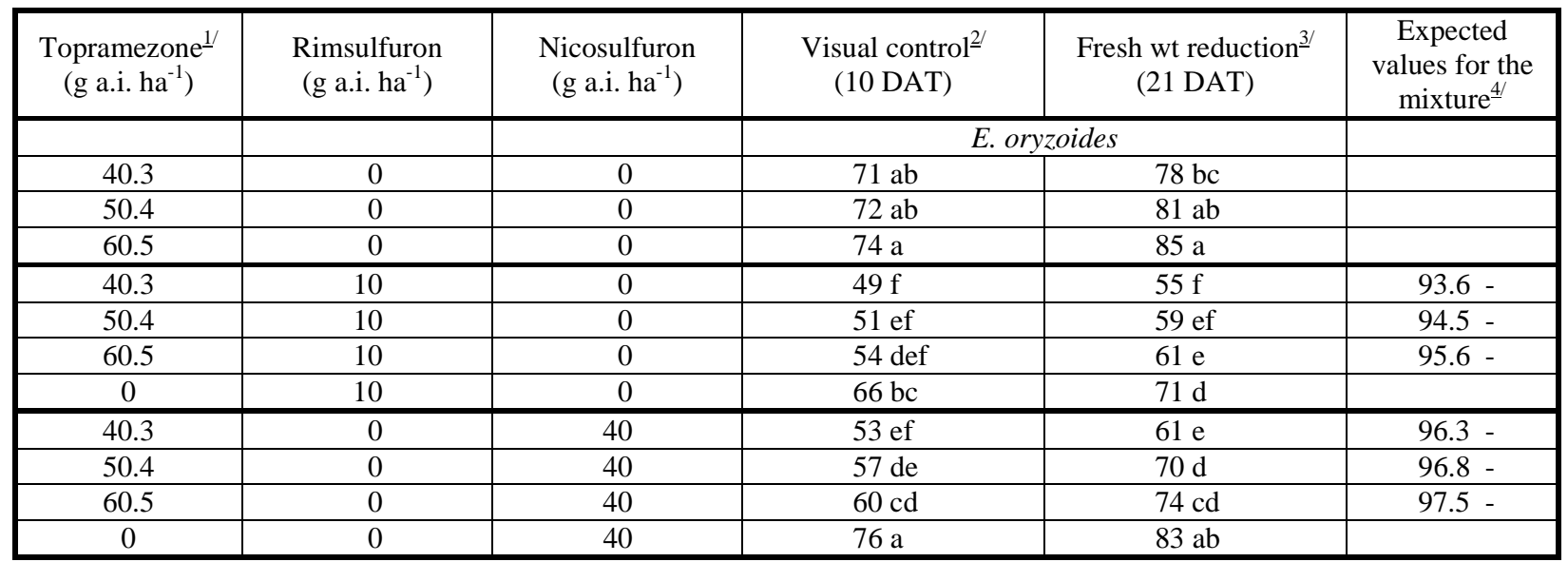

1/ Methylated seed oil (mixture of fatty acid esters and alkoxylated alcohols-phosphate esters) at 0.33\% v/v added to all topramezone treatments. $\stackrel{2}{2}$ Visual control on a scale from 0 to $100 \%(0 \%=$ no visual symptoms and $100 \%=$ dead plants $)$. Different letters within each variable indicate statistically significant differences at $P<0.05 .{ }^{3 /}$ Fresh weight of surviving plants expressed as a percent reduction from the non-treated control. 4/The minus sign (-) denotes antagonistic interaction according to Colby’s model. 
yellowing or purpling of the leaves for the sulfonylurea herbicides). Nevertheless, the plants showed symptoms of stunting and retardation of growth, but remained almost green until the end of the experiments.

At 10 DAT, visual control of E. phyllopogon with topramezone alone at $40.3 \mathrm{~g}$ a.i. ha ${ }^{-1}$ was on average $66 \%$ (Table 2). Similar to E. oryzoides, visual symptoms of herbicide efficacy also included bleaching (whitening of the leaves), which was evident within a week after spraying. Increasing topramezone rate to $50.4 \mathrm{~g}$ a.i. ha ${ }^{-1}$ did not improve visual control of E. phyllopogon (69\%), whereas the $60.5 \mathrm{~g}$ a.i. ha ${ }^{-1}$ rate resulted in a significantly higher visual control (73\%). At $21 \mathrm{DAT}$, an average fresh weight reduction of $68 \%$ was observed for E. phyllopogon with topramezone alone at $40.3 \mathrm{~g}$ a.i. $\mathrm{ha}^{-1}$. Increased rates of topramezone (50.4 and $60.5 \mathrm{~g}$ a.i. ha ${ }^{-1}$ ) did not improve the efficacy on E. phyllopogon (69\% and $73 \%$, respectively) at 21 DAT (Table 2). Also, topramezone at any rate applied plus rimsulfuron or nicosulfuron showed decreased efficacy on $E$. phyllopogon compared with topramezone alone at either 10 or 21 DAT (Table 2). Rimsulfuron alone was moderately effective on E. phyllopogon (63\%) at 21 DAT; however, rimsulfuron plus topramezone showed decreased control of E. phyllopogon (48-54\%) compared with rimsulfuron alone. Nicosulfuron alone was more effective on E. phyllopogon $(81 \%)$ than rimsulfuron alone, but the mixture of nicosulfuron plus topramezone showed decreased control of E. phyllopogon (52-60\%) compared with nicosulfuron alone (Table 2). In most cases, the lower control with the mixtures was more obvious in topramezone plus rimsulfuron than topramezone plus nicosulfuron. According to Colby's model, the observed percentages of fresh weight reduction in E. phyllopogon occurred by the combined application of topramezone plus rimsulfuron or topramezone plus nicosulfuron were significantly lower than the expected ones, corroborating antagonistic interaction of topramezone with rimsulfuron or with nicosulfuron in mixture (Table 2). Similarly to what was observed for E. oryzoides, plants of E. phyllopogon treated with all the herbicide mixtures did not express the typical visible symptoms of injury of either group of herbicides used. However, the plants showed symptoms of stunting and retardation of growth, but no reduction in the greenness for the duration of the experiments.

Topramezone alone at any rate applied provided $99 \%$ P. miliaceum control at 10 DAT (Table 3). Similarly, complete control of $P$. miliaceum was observed at 21 DAT in terms of fresh weight reduction. Visual symptoms of $P$. miliaceum control included bleaching (whitening of the leaves), followed by necrosis of the plants. Topramezone at $40.3 \mathrm{~g}$ a.i. $\mathrm{ha}^{-1}$ plus rimsulfuron showed decreased control of $P$. miliaceum than topramezone alone at either 10 or 21 DAT (Table 3). Increased rates of topramezone plus rimsulfuron improved control of $P$. miliaceum. In particular, the highest (unregistered) rate of topramezone plus rimsulfuron was the only rate that provided similar control of $P$. miliaceum $(100 \%)$ to that of topramezone alone $(100 \%)$ at 21 DAT (Table 3). According to Colby's model, the observed percentages of fresh weight reduction in $P$. miliaceum occurred by the combined application of topramezone plus rimsulfuron at the two lower rates of topramezone were significantly lower than the expected ones, corroborating antagonistic interaction of topramezone with rimsulfuron in mixture at those rates (Table 3). However, this was not the case for the highest rate of topramezone, where the observed percentage of fresh weight reduction in $P$. miliaceum occurred by the combined application of the highest rate of topramezone plus rimsulfuron was equal to the expected percentage (Table 3). Plants of $P$. miliaceum treated with the rimsulfuron mixture expressed some bleaching (whitening of the leaves), but to a much lesser extent than topramezone alone; plants showed symptoms of stunting, retardation of growth, and also necrotic leaf parts, but some of them retained green leaf parts for the duration of the experiments. On the other hand, topramezone at any rate plus nicosulfuron showed similar control of $P$. miliaceum to topramezone alone at either 10 or 21 DAT. Control of $P$. miliaceum with rimsulfuron or nicosulfuron (each applied alone) was high, ranging from 79 to $93 \%$ (Table 3).

Data from this study provided information about the efficacy of topramezone alone and in mixture with rimsulfuron or nicosulfuron 
Table 2 - Control of E. phyllopogon with topramezone alone and in mixtures applied at the 4- to 5-leaf growth stage (means are pooled over two locations)

\begin{tabular}{|c|c|c|c|c|c|}
\hline $\begin{array}{l}\text { Topramezone } \mathrm{e}^{\text {1/ }} \\
\left(\text { g a.i. ha }{ }^{-1}\right)\end{array}$ & $\begin{array}{l}\text { Rimsulfuron } \\
\text { (g a.i. ha }^{-1} \text { ) }\end{array}$ & $\begin{array}{l}\text { Nicosulfuron } \\
\left(\mathrm{g} \text { a.i. } \text { ha }^{-1}\right)\end{array}$ & $\begin{array}{l}\text { Visual control }^{2 /} \\
\text { (10 DAT) }\end{array}$ & $\begin{array}{l}\text { Fresh wt reduction }{ }^{3 /} \\
\text { (21 DAT) }\end{array}$ & $\begin{array}{c}\text { Expected } \\
\text { values for the } \\
\text { mixture }^{4 /}\end{array}$ \\
\hline & & & \multicolumn{2}{|c|}{ E. phyllopogon } & \\
\hline 40.3 & 0 & 0 & 66 bc & $68 \mathrm{~b}$ & \\
\hline 50.4 & 0 & 0 & $69 \mathrm{ab}$ & $69 \mathrm{~b}$ & \\
\hline 60.5 & 0 & 0 & $73 \mathrm{a}$ & $73 \mathrm{~b}$ & \\
\hline 40.3 & 10 & 0 & $45 \mathrm{~g}$ & $48 \mathrm{~g}$ & $88.2-$ \\
\hline 50.4 & 10 & 0 & $48 \mathrm{fg}$ & $52 \mathrm{fg}$ & $88.5-$ \\
\hline 60.5 & 10 & 0 & $52 \mathrm{ef}$ & 54 ef & $90.0-$ \\
\hline 0 & 10 & 0 & $59 \mathrm{~cd}$ & $63 \mathrm{c}$ & \\
\hline 40.3 & 0 & 40 & 50 efg & $52 \mathrm{fg}$ & $93.9-$ \\
\hline 50.4 & 0 & 40 & 55 de & 58 de & $94.1-$ \\
\hline 60.5 & 0 & 40 & $59 \mathrm{~cd}$ & $60 \mathrm{~cd}$ & $94.9-$ \\
\hline 0 & 0 & 40 & $74 \mathrm{a}$ & $81 \mathrm{a}$ & \\
\hline
\end{tabular}

1/ Methylated seed oil (mixture of fatty acid esters and alkoxylated alcohols-phosphate esters) at $0.33 \% \mathrm{v} / \mathrm{v}$ added to all topramezone treatments. ${ }^{2 /}$ Visual control on a scale from 0 to $100 \%(0 \%=$ no visual symptoms and $100 \%=$ dead plants $)$. Different letters within each variable indicate statistically significant differences at $P<0.05 .{ }^{3} /$ Fresh weight of surviving plants expressed as a percent reduction from the non-treated control. ${ }^{4} /$ The minus sign (-) denotes antagonistic interaction according to Colby's model.

Table 3 - Control of P. miliaceum with topramezone alone and in mixtures applied at the 4- to 5-leaf growth stage (means are pooled over two locations)

\begin{tabular}{|c|c|c|c|c|c|}
\hline $\begin{array}{l}\text { Topramezone }^{1 /} \\
\left(\text { g a.i. ha }{ }^{-1}\right)\end{array}$ & $\begin{array}{c}\text { Rimsulfuron } \\
\left.\text { (g a.i. ha }^{-1}\right)\end{array}$ & $\begin{array}{l}\text { Nicosulfuron } \\
\left.\text { (g a.i. ha }^{-1}\right)\end{array}$ & $\begin{array}{l}\text { Visual control }^{2 /} \\
\text { (10 DAT) }\end{array}$ & $\begin{array}{l}\text { Fresh wt reduction }{ }^{3 /} \\
\quad(21 \text { DAT })\end{array}$ & $\begin{array}{c}\text { Expected } \\
\text { values for the } \\
\text { mixture }^{4 /}\end{array}$ \\
\hline & & & \multicolumn{2}{|c|}{ P. miliaceum } & \\
\hline 40.3 & 0 & 0 & $99 \mathrm{a}$ & 99 а & \\
\hline 50.4 & 0 & 0 & $99 \mathrm{a}$ & $99 \mathrm{a}$ & \\
\hline 60.5 & 0 & 0 & $99 \mathrm{a}$ & $100 \mathrm{a}$ & \\
\hline 40.3 & 10 & 0 & $84 \mathrm{bc}$ & $89 \mathrm{c}$ & $99.9-$ \\
\hline 50.4 & 10 & 0 & $88 \mathrm{~b}$ & $95 \mathrm{~b}$ & $99.9-$ \\
\hline 60.5 & 10 & 0 & $98 \mathrm{a}$ & $100 \mathrm{a}$ & $100.0 \mathrm{~ns}$ \\
\hline 0 & 10 & 0 & 79 bcd & $85 \mathrm{~d}$ & \\
\hline 40.3 & 0 & 40 & $95 \mathrm{a}$ & $98 \mathrm{a}$ & $99.9 \mathrm{~ns}$ \\
\hline 50.4 & 0 & 40 & $99 \mathrm{a}$ & $99 \mathrm{a}$ & $99.9 \mathrm{~ns}$ \\
\hline 60.5 & 0 & 40 & $99 \mathrm{a}$ & $100 \mathrm{a}$ & $100.0 \mathrm{~ns}$ \\
\hline 0 & 0 & 40 & $85 \mathrm{~b}$ & $93 \mathrm{~b}$ & \\
\hline
\end{tabular}

1/ Methylated seed oil (mixture of fatty acid esters and alkoxylated alcohols-phosphate esters) at 0.33\% v/v added to all topramezone treatments. ${ }^{2} /$ Visual control on a scale from 0 to $100 \%(0 \%=$ no visual symptoms and $100 \%=$ dead plants $)$. Different letters within each variable indicate statistically significant differences at $P<0.05 . \stackrel{3}{ }$ Fresh weight of surviving plants expressed as a percent reduction from the non-treated control. ${ }^{4} / T h e$ minus sign (-) denotes antagonistic interaction according to Colby’s model.

on three annual grasses. Regarding the former, topramezone provided excellent control of $P$. miliaceum, but moderate control of E. oryzoides and less than moderate control of E. phyllopogon. This response indicates an obvious difference in the susceptibility to topramezone among the three grasses examined. Considering that the experiments of this study were conducted in pots, it could be logically hypothesized that more pronounced differences (than those observed in the present study) would be evident in the efficacy of topramezone under field conditions, as also observed in similar studies in the field (Damalas et al., 2012), where several parameters, other than the herbicides themselves, affect efficacy. Such parameters include the variable growth stage of weeds at application coupled with space availability in the field, which result in increased capacity of 
weeds for regrowth after herbicide application (Damalas et al., 2012); also, increased possibility for herbicide loss under field conditions often occurs. From a practical point of view, this finding means that in rescue (late) applications of topramezone in the field, control of E. oryzoides and E. phyllopogon could be significantly less. Similar results (i.e. decreased herbicide efficacy) on the activity of topramezone and of other herbicides with the same mode of action (HPPD-inhibiting herbicides), such as sulcotrione, have been reported on Echinochloa muricata (De Cauwer et al., 2012) as well as with certain ALSinhibiting herbicides, such as rimsulfuron, nicosulfuron, foramsulfuron, bispyribacsodium or penoxsulam and with certain ACCase-inhibiting herbicides, such as cyhalofop and clefoxydim, on the same grasses (i.e. E. oryzoides and E. phyllopogon) (Damalas et al., 2008, 2012). However, in a closely related species, E. crus-galli, topramezone provided $88 \%$ control (in terms of biomass reduction) when the plants were sprayed at the 5- to 6-leaf growth stage under controlled conditions (Soltani et al., 2012).

One reasonable explanation of this differential sensitivity to topramezone among the three grasses can be associated to the growth rate of each species, in the sense that species that grow slowly (e.g. E. phyllopogon) can possibly tolerate increased rates of herbicides, as observed in similar studies both under controlled and field conditions (Damalas et al., 2012). Nevertheless, other possible explanations, most likely owing to differences in width and position of the leaves among grasses, may also exist. Narrow and upright leaves in some grasses (e.g. E. phyllopogon) can yield lower deposits of spray solution on the leaf surface after spraying and thus can result in lower grass control, compared with wide and semi-prostrate leaves (e.g. P. miliaceum). These factors (i.e. growth rate and leaf position) probably explain the high control (88\%) of E. crus-galli (a species characterized by high growth rate and wide leaves) with topramezone when sprayed at the 5- to 6-leaf growth stage under controlled conditions (Soltani et al., 2012). Since the growth rate and growth stages can vary between species (Kudsk, 2002; Reade \& Cobb, 2002), in general high growth rates of weeds favor herbicide uptake and translocation to the targeted tissues, resulting in high herbicide efficacy. Especially for systemic herbicides (as those tested in the present study), low growth rate of weeds could potentially have negative effects on herbicide efficacy. This fact may have implications in the reduction of herbicide rates in various weed control programs as an approach to reduce production costs, minimize the risk of crop and non-target injuries, lessen carryover concerns, and diminish potential surface and groundwater contamination (Blackshaw et al., 2006; Kudsk, 2008). However, to adopt this approach without risk of weed control failures, other weed control tactics need to be adopted before farmers will be able to use reduced herbicide rates.

Data from this study also provided clear evidence that the activity of topramezone on the two Echinochloa spp. is largely reduced when topramezone is applied in mixture with rimsulfuron or nicosulfuron, indicating that the ALS-inhibiting herbicides tested in the present study can interact to a different extent with topramezone (an HPPDinhibiting herbicide). Such interaction was firstly reported by Kaastra et al. (2008) for topramezone plus nicosulfuron under controlled environment on $D$. sanguinalis and $E$. crus-galli and also under field conditions on E. crus-galli and, to a lesser extent, on $S$. viridis var. major. In particular, Kaastra et al. (2008) reported that the chemistries of these two herbicide groups (i.e. ALS-inhibiting herbicides and HPPD-inhibiting herbicides) exhibit potential for a two-way antagonistic interaction. In the present study, the single application of both ALS-inhibiting herbicides (rimsulfuron and nicosulfuron) permits a twoway comparison. In this sense, the decreased efficacy of the mixtures on E. oryzoides and E. phyllopogon below the efficacy of each single herbicide applied alone suggests that the efficacy of each herbicide alone was reduced when applied in mixture. For this reason, no typical visible symptoms of herbicide efficacy (e.g. bleaching or purpling) were observed when these herbicides were applied in mixture. By contrast, this was not the case for $P$. miliaceum, where only mixtures of topramezone with rimsulfuron showed a slight decrease in the control of $P$. miliaceum 
compared with topramezone alone. This response of the mixtures on $P$. miliaceum suggests an efficacy reduction of topramezone compared with the single application, but not in that of either rimsulfuron or nicosulfuron. From a practical point of view, this slight interaction appears to be of minor importance and most likely would escape farmers' attention. In light of these results, the potential for a two-way antagonistic interaction that was proposed by Kaastra et al. (2008) was confirmed in the mixtures of topramezone with rimsulfuron or with nicosulfuron on the two Echinochloa spp. tested, but not on $P$. miliaceum. These results fully confirm (e.g. in the case of topramezone plus nicosulfuron) and further expand (e.g. in the case of topramezone plus rimsulfuron) the results of Kaastra et al. (2008) on two different grasses (i.e. the two Echinochloa spp. studied in the present trials). Thus, in addition to an ALSinhibiting herbicide antagonizing an HPPDinhibiting herbicide, results indicated that certain HPPD-inhibiting herbicides can also reduce the efficacy of certain ALS-inhibiting herbicides as previous research has also shown (Schuster et al., 2007). According to our results, this potential for a two-way interaction tended to be species dependent, probably relating with species sensitivity to the herbicides tested, as well as herbicide dependent taking into account the different behavior of the mixtures with rimsulfuron or with nicosulfuron on $P$. miliaceum. Thus, a general assumption for a two-way interaction may be not valid for all HPPD-inhibiting or ALS-inhibiting herbicides.

Generally, the antagonistic behavior between two herbicides could be the result of a sub-optimum spray solution formation when the single herbicides are mixed (Damalas, 2004). In the present study, the possibility of a sub-optimum spray solution formation cannot be ruled out as a potential cause for the decreased control of Echinochloa in the mixtures studied, despite the fact that in the trials of this study the herbicides were applied strictly according to the label recommendations. In this respect, the cause of interaction in our case does not seem to be chemical incompatibility between companion herbicides in the spray solution before entering the plants, given that both the mixtures and the separate applications (herbicides alone) showed high efficacy on $P$. miliaceum. If chemical incompatibility before entering plants was the case, the mixtures would be less active on $P$. miliaceum as well. For example, the decreased efficacy (89\% control) of topramezone at the rate of $40.3 \mathrm{~g}$ a.i. ha ${ }^{-1}$ plus rimsulfuron on $P$. miliaceum (Table 3) compared with topramezone alone at the same rate $(99 \%$ control) contrary to the increased efficacy of the same mixture compared with rimsulfuron alone (85\% control) indicated that the reduction in the efficacy of the mixture was due to rimsulfuron. However, the similar efficacy (98\% control) of topramezone at the rate of $40.3 \mathrm{~g}$ a.i. ha ${ }^{-1}$ plus nicosulfuron on $P$. miliaceum to that of topramezone alone at the same rate $199 \%$ control) showed that nicosulfuron did not have any significant effect on the efficacy of topramezone plus nicosulfuron mixture on P. miliaceum (Table 3). A possible explanation for the reduced efficacy of the mixtures on the Echinochloa spp. tested is that after application the mixed herbicides might restrict the translocation of each other to the site of action or they might induce metabolism, thereby impeding herbicide activity on the grasses (Damalas \& Eleftherohorinos, 2001; Damalas, 2009); however, this issue requires further and more thorough investigation. From our experience, the growth rate of each species, as explained above, probably plays a major role in herbicide translocation and metabolism, which may result in different intensity of herbicide interactions among species.

Overall, data of this study provide new information on the activity of topramezone on E. oryzoides and E. phyllopogon, for which no data exist in the literature. Topramezone alone provided moderate efficacy on $E$. oryzoides or less than moderate efficacy on E. phyllopogon and regarding compatibility with ALS-inhibiting herbicides used in maize, the activity of topramezone on these Echinochloa spp. was reduced with co-application of rimsulfuron and nicosulfuron. In reverse, topramezone activity in the mixtures reduced the efficacy of rimsulfuron or nicosulfuron on E. oryzoides and E. phyllopogon, suggesting a two-way interaction. By contrast, when the same mixtures were applied on $P$. miliaceum, a slight 
decrease in the efficacy of topramezone was observed only for the mixture with rimsulfuron, indicating a different response among the grasses examined. It appears that newly introduced or naturalized panicoid grasses may complicate chemical weed control (concerning appropriate herbicide rates) in the field and certainly require special care in the selection of companion herbicides for potential mixtures. Apart from the theoretical scientific background on herbicide efficacy in response to various parameters of the application (e.g. target weed species, growth stage, growth conditions, and companion herbicides), the information obtained from this study could have practical significance a) for farmers and field practitioners in the search of possible options for improved weed control in maize and b) for the pesticide industry for developing and positioning new herbicide products in the marketplace.

\section{LITERATURE CITED}

BLACKSHAW, R. et al. Reduced herbicide doses in field crops: a review. Weed Biol. Manage., v. 6, n. 1, p. 10-17, 2006.

CARRETERO, J. L. El género Echinochloa en el suroeste de Europa. Ann. Jard. Bot. Madrid, v. 38, n. 1, p. 91-108, 1981.

COLBY, S. R. Calculating synergistic and antagonistic responses of herbicide combinations. Weeds, v. 15, n. 1 , p. 20-22, 1967.

DAMALAS, C. A. et al. Control of early watergrass (Echinochloa oryzoides) and late watergrass (Echinochloa phyllopogon) with cyhalofop, clefoxydim, and penoxsulam applied alone and in mixture with broadleaf herbicides.

Weed Technol., v. 20, n. 4, p. 992-998, 2006.

DAMALAS, C. A. et al. Echinochloa species control in maize (Zea mays L.) with sulfonylurea herbicides applied alone and in mixtures with broadleaf herbicides. Crop Protec., v. 34, n. 1, p. 70-75, 2012.

DAMALAS, C. A. et al. Morphological and physiological variation among species of the genus Echinochloa in northern Greece. Weed Sci., v. 56, n. 3, p. 416-423, 2008.

DAMALAS, C. A. Herbicide tank mixtures: common interactions. Inter. J. Agric. Biol. v. 6, n. 1, p. 209-212, 2004.

DAMALAS, C. A. Pyrithiobac reduces control of green foxtail (Setaria viridis) and bristly foxtail (Setaria verticillata) by propaquizafop. Crop Protec., v. 28, n. 7, p. 616-618, 2009.
DAMALAS, C. A.; ELEFTHEROHORINOS, I. G. Dicamba and atrazine antagonism on sulfonylurea herbicides used for johnsongrass (Sorghum halepense) control in maize

(Zea mays). Weed Technol., v. 15, n. 1, p. 62-67, 2001.

DAYAN, F. E. et al. p-Hydroxyphenylpyruvate dioxygenase is a herbicidal target site for b-triketones from Leptospermum scoparium. Phytochemistry, v. 68, n. 14, p. 2004-2014, 2007.

DE CAUWER, B. et al. Differential sensitivity of Echinochloa muricata and Echinochloa crus-galli to 4hydroxyphenyl pyruvate dioxygenase- and acetolactate synthase-inhibiting herbicides in maize. Weed Res., v. 52, n. 6, p. 500-509, 2012.

EPPO. Design and analysis of efficacy evaluation trials. EPPO Bull., v. 42, n. 3, p. 367-381, 2012.

EPPO. Efficacy evaluation of herbicides: weeds in cereals. EPPO Bull., v. 37, n. 3, p. 482-485, 2007.

GITSOPOULOS, T. K. et al. Response of maize (Zea mays L.) to post-emergence applications of topramezone. Crop Protec., v. 29, n. 10, p. 1091-1093, 2010.

GORŠIĆ, M. et al. Weed control in maize with new herbicide topramezone. Cereal Res. Comm., v. 36, n. 5, p. 1627-1630, 2008.

GROSSMANN, K.; EHRHARDT, T. On the mechanism of action and selectivity of the maize herbicide topramezone: a new inhibitor of 4-hydroxyphenylpyruvate dioxygenase. Pest Manage. Sci., v. 63, n. 5, p. 429-439, 2007.

IMPACT ${ }^{\circledR}$ herbicide. Technical information and use guide. Los Angeles: AMVAC Chemical Corporation, 2007.

KAASTRA, A. C. et al. Two-way performance interactions among $\rho$-hydroxyphenyl pyruvate dioxygenase- and acetolactate synthase-inhibiting herbicides. Weed Sci., v. 56, n. 6, p. 841-851, 2008.

KOEPKE-HILL, R. M. et al. Herbicide combinations for control of volunteer potato. Weed Technol., v. 24, n. 2, p. 91-94, 2010.

KUDSK, P. Optimising herbicide dose: A straightforward approach to reduce the risk of side effects of herbicides.

Environmentalist, v. 28, n. 1, p. 49-55, 2008.

KUDSK, P. Optimising herbicide performance. In: NAYLOR, R. L. Weed Management Handbook. 9 ed. Oxford: Blackwell, 2002. p. 323-344.

MORAN, G. R. 4-Hydroxyphenylpyruvate. Arch. Biochem. Biophys., v. 433, n. 1, p. 117-128, 2005. 
READE, J. P. H.; COBB, A. Herbicides: Modes of action and metabolism. In: NAYLOR R. L. Weed Management Handbook. 9 ed. Oxford: Blackwell, 2002. p. 134-170.

SCHUSTER, C. L. et al. Mechanism of antagonism of mesotrione on sulfonylurea herbicides. Weed Sci., v. 55, n. 5, p. 429-434, 2007.
SOLTANI, N. et al. Efficacy of topramezone and mesotrione for the control of annual grasses. Inter. Res. J. Agric. Sci. Soil Sci., v. 2, n. 1, p. 46-50, 2012.

WILLIAMS, J. F. Rice nutrient management in

California. Oakland: University of California, Division of Agricultural and Natural Resources, 2010. (Publication, 3516). 